\title{
PENERAPAN DISASTER RECOVERY AND CONTINGENCY PLANNING PADA PERLINDUNGAN ARSIP VITAL DI BPN DIY
}

\author{
Lastria Nurtanzila \\ Program Studi Kearsipan, Sekolah Vokasi, Universitas Gadjah Mada \\ lastrianurtanzila@ugm.ac.id
}

\begin{abstract}
Protection of vital records in an organization is a must. The position of the vital records in the organization's performance enables the organization to do some protection to its vital records. This study aims to analyze the application of disaster recovery and contingency plan in the protection of vital records in the Yogyakarta Land Regency. This research uses qualitative approach with case study research method. Data analysis is used to identify any vital rechords managed by BPN DIY, as well as possible disasters. Disaster Recovery and Contingency Plan concept is used to perform strategy mapping in disaster management for protection of vital records at BPN DIY. The results of this study are expected to gives recommendations to government for the implementation of disaster management strategies (pre disaster, during disasters and post disaster) to vital records in government agencies.
\end{abstract}

Keywords : Disaster Recovery and Contingency Plan, Vital Records, Disaster Management.

\section{Intisari}

Perlindungan arsip vital dalam suatu organisasi merupakan keharusan. Posisi arsip vital dalam kinerja organisasi memungkinkan organisasi untuk melakukan perlindungan terhadap arsip vitalnya. Penelitian ini bertujuan untuk menganalisis penerapan Disaster Recovery and Contingency Plan dalam perlindungan arsip vital di Daerah Istimewa Yogyakarta. Penelitian ini menggunakan pendekatan kualitatif dengan metode penelitian studi kasus. Analisis data digunakan untuk mengidentifikasi setiap arsip vital yang dikelola oleh BPN DIY, serta kemungkinan terjadinya bencana. Konsep Disaster Recovery and Contingency Plan digunakan untuk melakukan pemetaan strategi dalam penanggulangan bencana untuk perlindungan arsip vital di BPN DIY. Hasil penelitian ini diharapkan dapat memberikan rekomendasi kepada pemerintah untuk pelaksanaan strategi penanggulangan bencana terhadap arsip vital di lembaga pemerintah (pra bencana, selama bencana dan pasca bencana).

Kata kunci: Disaster Recovery and Contingency Plan, arsip vital, manajemen bencana 


\section{PENDAHULUAN}

Indonesia, secara umum, memiliki frekuensi bencana alam cukup tinggi karena posisi geografisnya. Bencana ini beragam mulai dari bencana ringan hingga bencana dengan kategori luar biasa. Tercatat dalam sejarah, letusan Krakatau (1883), Merapi (2010) hingga tsunami di Aceh (2004) meninggalkan kerusakan jangka panjang bagi Indonesia. Bencana yang disebutkan terakhir, bahkan, menyisakan program penyelamatan dan pemulihan (recovery) arsip yang masih berlangsung hingga tahun 2017. Bahkan, akibat besarnya dampak tsunami Aceh, maka dibangun Balai Arsip Tsunami Aceh yang diawasi langsung oleh Arsip Nasional Republik Indonesia (anri.go.id). Rerata, arsip yang masuk dalam program recovery adalah aset arsip pada bidang agraria.

Dalam Peraturan Pemerintah No.28 Tahun 2012 tentang Kearsipan, disebutkan beberapa jenis arsip, salah satunya adalah arsip vital, "arsip vital adalah arsip yang keberadaannya merupakan persyaratan dasar bagi kelangsungan operasional pencipta arsip, tidak dapat diperbarui, dan tidak tergantikan apabila rusak atau hilang". Sehingga dapat dikatakan bahwa arsip vital merupakan arsip yang sangat dibutuhkan keberadaannya oleh suatu organisasi, apabila arsip tersebut hilang atau rusak maka akan terhenti aktivitas organisasi, sehingga organisasi tidak dapat menyusun kembali rekaman informasi yang dapat diterima.

Dalam hal manajemen terhadap kemungkinan terjadinya bencana dan proses pemulihan pascabencana dikenal sebuah konsep yaitu Disaster Recovery And Contingency Plan atau dapat pula disingkat menjadi DRCP. DRCP sendiri awalnya diperkenalkan pada perusahaanperusahaan swasta yang memang memiliki konsentrasi tinggi pada arsip dan aset mereka. Perlindungan pada aset dan arsip vital sangat diperhatikan mengingat informasi sangat dibutuhkan untuk pelaksanaan kegiatan organisasi. Konsep mengenai DRCP sendiri diawali dengan konsep tentang manajemen resiko dari suatu organisasi. Dalam pengelolaan organisasi permasalahan risiko seringkali tidak menjadi perhatian manajemen. Padahal dalam konsep pengelolaan yang berkelanjutan sebuah organisasi didirikan dengan asumsi untuk terus beroperasi sampai jangka waktu yang tidak terbatas. Risiko seringkali menjadi faktor penghambat operasi sebuah organisasi untuk mencapai tujuan. Organisasi profit memiliki kesadaran tinggi akan perlunya mengelola risiko sehingga muncul konsep pengendalian internal. Tidak begitu lama muncul konsep manajemen risiko yang secara khusus berfokus pada pengelolaan risiko.

Pada dasarnya DRP dan BCP dibutuhkan untuk menganalisis dan mengidentifikasi kemungkinankemungkinan risiko dalam suatu proses kerja yang dapat diantisipasi dengan menyusun rencana darurat untuk menangani permasalahan yang timbul akibat risiko-risiko tersebut. Meskipun pendekatan ini banyak ditemui pada organsiasi swasta dan baiasanya digunakan untuk kegiatan perlindungan aset, namun dalam penelitian ini mencoba menguraikan pendekatan DRCP untuk perlindungan arsip vital. Tentunya secara kontekstual pendekatan ini dapat diterapkan, mengingta pengamanan aset menguatakan perlindungan begitupula dengan pengamanan aset vital yang juga membutuhkan perlindungan.

Dimulai dari indentifikasi arsip vital apa saja yang ada pada suatu organisasi tersebut, apa saja kemungkinan bencana yang dapat mengancam eksistensi arsip vital teresebut, dan bagaimana DRCP nya. Pada penelitian ini, peneliti memilih lokasi organisasi yanga kan dilakukan 
analisis adalah Badan Pertanahan Nasional Daerah Istimewa Yogyakarta. Pemilihan lokasi ini dikarenakan beberapa alasan yang dapat diuraikan sebagi berikut ;

a. BPN DIY merupakan instasni yang berwenang dalam perumusan kebijakan tentang pertanahan, sementara permasalahan pertanahan adalah masalah yang komples dan vital bagi kehidupan publik.

b. Sebagai instansi yang berwenang dalam perumusan kebijakan dan pelaksanaan kebijakan, banyak arsip-arsip vital yang disimpan dan harus dikelola dengan baik oleh BPN DIY agar tidak menimbulakn konflik di kemudian hari.

c. Selama ini belum ada penelitian secara detail tentang penerapan DRCP untuk mengelola arsip vital di BPN DIY.

Korelasi antara resiko bencana dan keselamatan arsip argaria menjadi alasan tim peneliti dari Program Studi Kearsipan untuk menggali informasi dan menawarkan suatu program perencanaan penanganan arsip pasca bencana kepada Badan Pertanahan Yogyakarta. Region Yogyakarta dipilih sebab area ini memiliki tingkat kemungkinan bencana alam yang tinggi terkait dengan posisi geografisnya. Keberadaan Gunung Merapi yang masih aktif memiliki resiko bencana vulkanik. Sementara di sisi selatan, Palung Jawa yang merupakan jalur subduksi lempeng Indo-Australia-Eurasia memiliki resiko gempa tektonik. Ancaman di atas belum termasuk bencana yang lebih ringan seperti angina puting beliung, tanah longsor, banjir dan lain sebagainya. (Bappenas, 2010).

Penelitian ini bertujuan untuk memberikan gambaran mengenai perencanaan yang dapat dilakukan untuk menyelamatkan sebanyak mungkin asset berupa arsip yang tergolong vital bagi suatu organisasi. Diharapkan pula, rancangan ini dapat menjadi contoh bagi organisasi serupa untuk menggiatkan kesadaran bagi penyelamatan arsip, terutama arsip yang menyangkut hajat hidup orang banyak. Dalam lingkup lebih sempit, kajian ini dapat dijadikan acuan bagi individu tentang penanganan arsip vital seperti sertifikat tanah. Pengetahuan ini relevan seiring dengan program Presiden Joko Widodo tentang pendaftaran tanah dan pembagian sertifikat bagi warga sebagai bukti hak atas tanah (Kompas, 2017). Direncanakan pada 2025, seluruh tanah di Indonesia sudah terpetakan dan terdaftar. Pengelolaan dokumen pertanahan selayaknya saling berkorelasi sehingga dapat mencerminkan fungsi-fungsi BPN DIY. Namun dalam berbagai riset mengenai arsip pertanahan belum ditemukan upaya untuk mengkorelasikan pengelolaan arsip-arsip tersebut sehingga tingkatan atau kelas arsipnya sulit untuk diidentifikasi. Oleh karena itulah penelitian ini mencoba menganalisis penerapan konsep disaster recovery and contingency planning pada perlindungan arsip vital di BPN DIY.

\section{METODE PENELITIAN}

Penelitian ini menggunakan pendekatan kualitatif dengan jenis studi kasus, yaitu meneliti suatu kasus yang terjadi pada tempat dan waktu tertentu dan mencari kontekstual tentang setting kasus tersebut, dengan mengumpulkan materi yang banyak dari sumber-sember informasi yang jelas untuk mendapatkan gambaran kasus secara detail (Satori dan Komariah , 2009 : 36). Penelitian ini merupakan penelitian yang bersifat yuridis empiris karena penelitian ini menitikberatkan pada penelitian lapangan secara menyeluruh, sistematis, dan akurat, serta ditunjang dengan penelitian kepustakaan serta data-data sekunder yang sudah tersedia sebelumnya. Hasil dari penelitian ini 
adalah deskriptif analitis. Bersifat deskriptif karena dari penelitian ini diharapkan dapat memperoleh gambaran secara menyeluruh mengenai penerapan disaster recovery and contingency planning dalam perlindungan terhadap arsip vital di BPN DIY

\section{HASIL DAN PEMBAHASAN}

\section{Analisis Organisasi BPN}

Badan Pertanahan Nasional (BPN) adalah Lembaga Pemerintah Non Kementrian yang berada di bawah dan bertanggung jawab kepada Presiden dan dipimpin oleh Kepala. (Sesuai dengan Perpres No. 63 Tahun 2013). Badan Pertanahan Nasional mempunyai tugas melaksanakan tugas pemerintahan di bidang pertanahan secara nasional, regional dan sektoral sesuai dengan ketentuan peraturan perundangundangan. Secara umum, BPN memiliki 4 prinsip utama dalam pengelolaan pertanahan, yaitu :

1. Pengelolaan pertanahan harus mampu berkonstribusi pada kesejahteraan masyarakat,

2. Pengelolaan pertanahan harus mampu berkonstribusi pada keadilan penguasaan dan pemilikan tanah,

3. Pengelolaan pertanahan harus mampu berkonstribusi pada keberlanjutan sistem kemasyarakatan dan Kebangsaan Indonesia,

4. Pengelolaan pertanahan harus mampu berkonstribusi pada harmoni sosial.

\section{Analisis Kearsipan BPN}

Arsip vital dalam suatu organisasi, tidak hanya berupa arsip aktif, tetapi juga dapat mencapai masa in-aktif (Ricks, 1992: 244). Media arsip vital pun dapat berupa hard copy, pita magnetic, mikro film, optical disc, dan lain-lain (Ricks, 1992: 244). Dalam studi kasus di Badan
Pertanahan Nasional Kanwil Yogyakarta, media arsip vital berupa kertas atau hard copy. Oleh karena arsip vital dapat berupa aktif dan in-aktif, maka prosedur pengelolaannya pun didasarkan pada standar pengelolaan arsip aktif dan inaktif.

Pengelolaan arsip aktif mengacu pada pemberkasan arsip yang diperkirakan mencapai $25 \%$ dari keseluruhan arsip yang ada di suatu organisasi (Ricks, 1992). Persentase tersebut tidak hanya berupa arsip vital organisasi, tetapi juga termasuk klasifikasi arsip penting, berguna, dan biasa. Meski demikian, metode pemberkasan untuk arsip vital pun sebagaimana metode pemberkasan pada arsip-arsip substanstif. Sistem pemberkasan yang digunakan untuk menata arsip buku tanah adalah kombinasi sistem kronologis dengan sistem geografis.

Penggunaan sistem geografis didasarkan pada lokasi tanah yang direkam dalam arsip vital. Menurut Place dan Hyslop (1982)sistem geografis tepat digunakan pada organisasi yang prosedur kerjanya berbasis kewilayahan. Potensi kelemahan yang timbul akibat penggunaan sistem tersebut adalah apabila terdapat beberapa wilayah yang memiliki nomenklatur sama. Selain itu, sistem geografis akan menemui kerumitan apabila digabungkan dengan kode alphabetik. Oleh karena itu, penataan arsip vital aktif di BPN pun menggunakan sistem pemberkasan numerik, yaitu mengacu pada kode wilayah tingkat kelurahan.

Prosedur penataan buku tanah, yaitu:

1. Arsip buku tanah disimpan dalam personal file sesuai dengan wilayah tanah, kemudian berdasarkan tahun pendaftaran tanah. Arsip dengan angka tahun paling baru diletakkan di lembar awal. Satu personal Gile 
dapat memuat 50 (lima puluh) buku tanah.

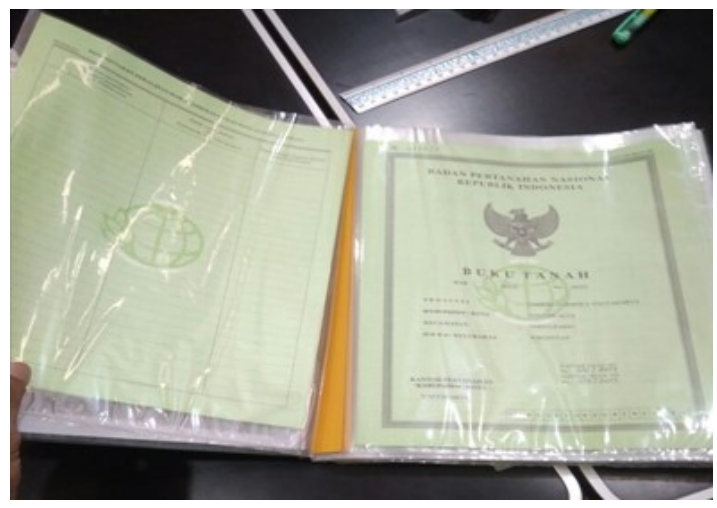

2. Personal file berisi buku tanah kemudian disimpan dalam roll o'pack dengan terlebih dahulu diberikan kode alphabetic (menunjukkan wilayah tanah) dan kode numerik (menunjukkan kode wilayah tanah). Wilayah tanah dalam ini mengacu pada wilayah tingkat kelurahan.

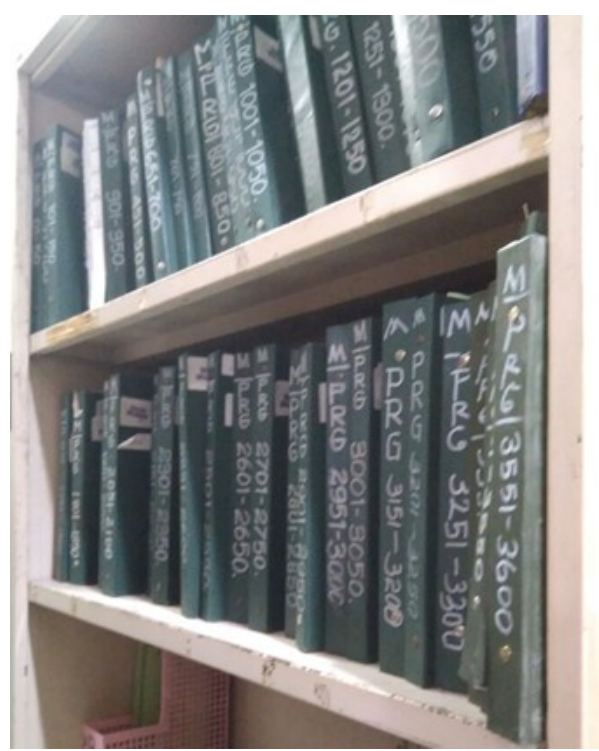

Untuk arsip yang belum disimpan dalam personal Gile folder, sarana simpan sementara menggunakan box file dengan prosedur sebagaimana dalam personal file folder. Namun kode yang digunakan dalam box file hanya berupa kode alphabetic.

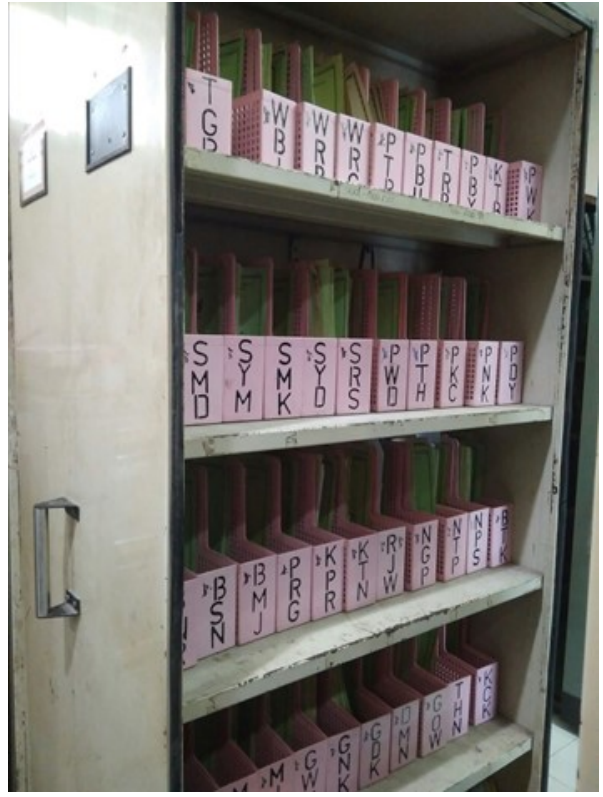

Prosedur penataan tersebut memiliki kelebihan, yaitu karena fungsi kerja BPN adalah per wilayah, maka penemuan kembali berdasarkan wilayah dan kode wilayah tersebut dapat dikatakan mudah. Namun pada sisi kelemahan, yaitu pemanfaatan personal file folder, pada dasarnya tidak sesuai dengan jenis arsip buku tanah. Hal ini karena untuk penemuan kembali detail informasi dalam buku tanah membutuhkan waktu lebih lama dibandingkan menemukan kembali satu buku tanah. Apabila BPN tetap menggunakan sarana personal file folder, maka daftar berkas dan daftar isi berkas harus dibuat untuk kemudahan dalam penemuan kembali arsip buku tanah. Adapun prosedur dalam penataan arsip buku tanah yang telah memasuki masa inaktif, tidak jauh berbeda dengan penataan pada masa aktifnya. Hal ini menyesuaikan dengan prinsip original order, yaitu mempertahankan penataan awal arsip.

\section{Pengelolaan Arsip Vital BPN}

Definisi arsip vital mengacu pada dokumen yang memiliki nilai urgensi tak tergantikan dan dapat mengakibatkan 
hilangnya aspek administratif, keuangan, hingga hukum apabila dokumen tersebut hilang atau rusak. Surotani (2013) menyebutkan arsip vital adalah bukti penyelenggaraan kegiatan organisasi yang berfungsi sebagai akuntabilitas kinerja, bukti hukum, dan memori organisasi, baik yang terekam dalam bentuk media kertas maupun non-kertas. Ricks (1992: 244) menekankan bahwa "vital records are those records essential to the continued life of a business, also called class 1 records". Arsip vital, apabila merujuk pada ke dua pakar tersebut, dapat dimaknai sebagai arsip kelas 1 yang memiliki nilai vital bagi eksistensi organisasi, baik secara administratif, keuangan, maupun hukum. Pernyataan tersebut senada dengan Perka ANRI Nomor 06 Tahun 2005 tentang Pedoman Perlindungan, Pengamanan, dan Penyelamatan Dokumen/Arsip Vital, yang menjabarkan bahwa:

Arsip vital merupakan informasi terekam yang sangat penting dan melekat pada keberadaan dan kegiatan organisasi yang di dalamnya mengandung informasi mengenai status hukum, hak dan kewajiban serta aset kekayaan instansi dan apabila hilang tidak dapat diganti dan mengganggu keberadaan dan pelaksanaan kegiatan instansi.

Pada dasarnya, arsip vital yang dikelola oleh BPN DIY adalah cermin dari proses administrasi yang terjadi dalam pelaksanaan fungsi-fungsi BPN DIY tersebut. Jika berdasar pada proses administrasi, maka arsip vital yang tercipta tidak hanya berupa arsip sertifikat tanah, tetapi juga termasuk buku register tanah, peta atau denah ruang, data hasil survei pertanahan. BPN DIY, sebagai pembuat kebijakan dan penetapan keputusan hak pertanahan, tidak akan dapat menjalankan fungsinya apabila arsip buku register tanah maupun peta atau denah ruang tersebut rusak, bahkan hilang. Dalam hal ini, BPN DIY harus melakukan penganggaran kegiatan pengkajian ulang sejak survei hingga penetapan hak pertanahan yang tentunya tidak efektif dan efisien. Selain itu, kegiatan pengkajian ulang tersebut akan semakin sulit dan birokratis apabila tanah yang dikaji terjadi sengketa. Pengelolaan dokumen pertanahan selayaknya saling berkorelasi sehingga dapat mencerminkan fungsi-fungsi BPN DIY. Namun dalam berbagai riset mengenai arsip pertanahan belum ditemukan upaya untuk mengkorelasikan pengelolaan arsip-arsip tersebut sehingga tingkatan atau kelas arsipnya sulit untuk diidentifikasi.

Arsip vital BPN DIY jika dianalisis dari aspek struktur organisasi dapat diperhatikan dari tugas dan fungsi yang melekat di masing-masing unit kerja sebagai berikut:

1. Bidang infrastruktur pertanahan, menciptakan arsip hasil survei, pengukuran dan pemetaan;

2. Bidang hubungan hukum pertanahan, menciptakan arsip produk hukum yang memutuskan hak-hak pertanahan;

3. Bidang penataan pertanahan, menciptakan arsip yang mencerminkan kegiatan pemanfaatan pertanahan dan penataan kawasan tertentu;

4. Bidang pengadaan tanah, menciptakan arsip hasil penilaian tanah, data pengadaan dan pemanfaatan tanah pemerintah;

5. Bidang penanganan masalah dan pengendalian pertanahan, menciptakan arsip proses penyelesaian sengketa pertanahan.

Pengelolaan arsip vital di BPN sendiri dilakukan oleh SDM khusus yang merupakn pegawai BPN dengan latar belakang non-kearsipan dibantu satu 
orang pegawai honorer. Tentunya hal ini menjelaskan mengapa penataan arsip di bPN masih belum maksimal. Selain itu penyimpangan arsip sudah menggunakan ruang simpan sendiri yaitu sebanyak 4 ruang, meski demikian 2 ruang diantaranya dinilai kurang layak karena belum memperhatikan faktor suhu dan kelembapan serta keamanan fisik dari pencurian. ${ }^{1}$ Pada dasarnya terdapat dua jenis arsip yang dikategorikan sebagai arsip vital yaitu arsip buku tanah (merupakan arsip yang informasi didalamnya hampir sama dengan sertifikat tanah, sertifikat tanah dipegang pemohon, sedangkan buku tanah disimpan BPN, informasi didalam buku tanah meliputi keterangan pemilik tanah, hasil ukur tanah, dan keterangan lokasi tanah, sehingga ketika sertifikat tanah pemilik rusak/ hilang, cara pengurusan kembali cukup melihat data-data yang terdapar pada buku tanah yang disimpan BPN), kedua adalah arsip warkah (merupakan arsip yang didalamnya berisi berkas-berkas persyaratan permohonan pembuatan sertifikat tanah, seperti KTP, KK, surat pernyataan kepemilikan, surat ukur tanah, gambar ukur tanah, dan berkas lainnya dalam proses pembuatan sertifikat tanah yang bersifat administratif)

Berdasarkan struktur organisasi tersebut pun dapat diperhatikan bahwa proses administrasi antar bidang saling berkorelasi. Proses yang saling berkorelasi tersebut mengindikasikan bahwa pengelolaan arsip yang diciptakan masing-masing bidang sudah seharusnya juga saling berkaitan. Sebagai contoh, bidang hubungan hukum pertanahan tidak dapat menetapkan hak-hak pertanahan tanpa arsip-arsip yang diciptakan oleh bidang infrastruktur pertanahan. Dalam menetapkan hak-hak pertanahan, beberapa dokumen krusial yang menunjang diantaranya arsip hasil

1 Wawancara dengan pihak BPN 22 September 2017, pukul 09.07 WIB. survei, pengukuran dan pemetaan tanah. Apabila arsip-arsip tersebut tidak dikelola sesuai standar kearsipan, maka pemutusan hak-hak pertanahan tidak akan mencerminkan kondisi real di lapangan.

Persentase arsip vital, menurut Ricks (1992), ada pada kisaran 3-5 \% dalam suatu organisasi. Meskipun memiliki persentase yang minim, efektivitas operasional organisasi akan tercapai apabila arsip vital tersebut dikelola sesuai standar sehingga persentase kehilangan menjadi kecil. Suatu organisasi, sebelum melakukan pengelolaan arsip vital, perlu memahami lebih dahulu ciri-ciri dari arsip vital, yaitu:

1. Harus ada demi kelangsungan hidup organisasi;

2. Memerlukan perlindungan dan pengamanan;

3. Fisik arsip tidak dapat digantikan;

4. Merupakan aset organisasi;

5. Alat dasar manajemen

\section{Analisis DRCP}

Pada dasarnya DRP dan BCP dibutuhkan untuk menganalisis dan mengidentifikasi kemungkinankemungkinan risiko dalam suatu proses kerja yang dapat diantisipasi dengan menyusun rencana darurat untuk menangani permasalahan yang timbul akibat risiko-risiko tersebut. Oleh karena itulah , untuk memahami konsep ini perlu dipahami lebih dahulu tentang bencana. Bencana sendiri diartikan sebagai kerusakan serius yang terjadi pada banyak orang, material maupun lingkungan yang mana mendorong kemampuan para pihak yang terkena bencana tersebut untuk menanganinya menggunakan sumberdayanya sendiri (Asian Disaster Reduction Center, 6447). Dalam penelitian ini tentunya bencana dikhususkan pada kerusakan material, 
sebagaimana dimaksudkan material merupakan arsip vital dalam sebuah organisasi.

Sementara Shaluf (2007), melakukan kategorisasi bencana menjadi tiga bentuk, yaitu:

1. Natural disasters, yaitu kerusakan yang disebabkan oleh kerusakan alamiah atau natural. Natural disaster bisa berasal dari internal (permukaan bumi), eksternal (topografi), cuaca (meteorologi dan hidrologi) dan fenomena biologis. Natural disasters sering juga disebut sebagai "Act of God", dalam pengartian istilah ini, penulis artikel memaknai natural disater merupakan kejadian yang berasal dari Tuhan, atau merupakan kehendak Tuhan, bukan buatan manusia ataupun rekayasa teknologi. Contoh dari bencana tipe ini adalah, gempa bumi, tsunami, gunung meletus, longsor, angin puting beliung, tornado, ombak besar, banjir, badai, hama serangga, dan penyakit-penyakit epidemik.

2. Man-made disaster, yaitu kerusakan yang dihasilkan akibat dari keputusan manusia. Bencana ini dapat berlangsung dalam waktu yang cukup lama maupun secara mendadak. Bencana yang bersifat mendadak ini sering juga disebut sebagai bencana sosio-teknikal yang terbagi menjadi 4 kategori, yaitu kegagalan/kerusakan pabrik dan perkebunan, kerusakan transportasi, kerusakan pada tempat publik, dan kerusakan produksi. Sementara bencana jangka panjang lebih mengarah pada konflik-konflik yang terjadi baik secara nasional maupun internasional. Man-made disasters, termasuk didalamnya adalah bencana sosio-teknikal dan warfare. Bencana sosio-teknikal terjadi karena eror dari pihak manusia, teknis dan operasional.

3. Hybrid disasters, yaitu bencana yang disebabkan oleh gabungan antara keduanya, kerusakan yang terjadi merupakan akibat dari faktor alamiah dan keputusan manusia. Contoh dari bencana tipe ini adalah, adanya penggundulan hutan oleh para pembalak kayu liar menyebabkan terjadinya kebakaran hutan dan longsor dibeberapa lereng akibat derasnya air hutan tidak tertampung/tertahan. Hybrid disaster ini kadang membawa pada subsequent disaster yang memiliki dampak secara ekonomi dan sosial.

Adapun di BPN sendiri kesdaran tentang identifikasi bencana yang mungkin dialami masih belum nampak, secara umum pihak BPN lebih memperhatikan pada bencana tipe 2 yaitu bencana akibat ulah manusia, seperti pencurian. ${ }^{2}$ Sehingga upaya perlindungan masih sebatas cctv dan pintu yang selalu dikunci oleh petugas yang keluar masuk. Hal ini dimungkinkan karena sampai saat ini resiko yang sering dialami hanya sebatas arsip terselip atau hilang. Sementara kasus-kasus seperti banjir maupun kebakaran belum pernah dialami. Dari sudut paradigma DRCP tentunya hal ini tidak baik, organisasi haruslah memahami apa saja yang mungkin menjadi resiko/bencana. Perencanaan terhadap manajemen bencana dimulai dari indentifikasi aset apa saja yang dimiliki organisasi. Beberapa aset vital yang dimiliki organisasi seperti ;

1. Komputer

2. Arsip elektronik

3. Arsip non-elektronik

4. Server data

5. Sumber daya Manusia

2 Wawancara dengan pihak BPN 22 September 2017, pukul 10.00 WIB. 
Melihat kasus yang terjadi di BPN, nampaknya perlu dilakukan perencanaan manajemen resiko yang matang dari suatu instansi pemerintahan, diantaranya melalui 3 tahapan, yaitu :

1. Tahapan pra-bencana

Dalam tahapan ini yang paling penting adalah mengidentifikasi arsip apa saja yang perlu diselamatkan pada saat bencana terjadi , baik arsip elektronik maupun fisik. Untuk arsip fisik perlu dipikirkan desain bangunan seperti posisi ruang simpan lebih baik dekat dengan jalur mitigasi bencana. Penyimpanan menggunakan roll o'pack dinilai sudah cukup untuk pengamanan dari bahaya api mapun air, meski demikian perlu diperlukan alih media agar arsip tetap tersimpan dalam bentuk digital. Setiap intansi pemrintahan haruslah memiliki server pendukung, sehingga bila server utama terkena virus, maka backup data dapat dilakukan. Alat pemadam kebakaran dan juga jalur mitigasi bencana juga harus terpasang di dalam gedung. Hal yang paling utama adalah melakukan sosialisais dan simulasi apabila terjadi bencana kepada para pegawai sehingga pegawai tidak panik dan kebingungan menghadapi bencana.

2. Tahapan saat bencana

Dalam tahapan ini hal yang perlu dilakukan adalah menjalankan SOP mitigasi bencana. SOP tersebut harulah disusun sebelumnya, jika diperlukan dapat dibentuk komite penanganan bencana. SDM biasanya akan panik dan melupakan aset organisasi, tentunya ini adalah hal yang wajar, namun demikian perlu ditetapkan tanggung-jawab masing-masing pegawai pada saat aksi penyelamatan, misalkan banjir terjadi, siapa saja yang haru ke gedung untuk menyelamatkan aset, atau saat kebakaran terjadi, pegawai menyalakan sensor air agar pipa mengeluarkan air secara otomatis, sembari pegawai menyelamatkan diri.

3. Tahapan setelah bencana

Dalam tahapan ini, fokus utama adalah recovery, hal ini biasanya dilakukan dengan cara mngeidentifikasi aset apa saja yng masih bisa diselamatkan, arsip fisik dipisahkan sesuai kategori kerusakannya, dan dilakukan proses penyelamatan selanjutnya. Sementara arsip elektronik dapat dipindahkan ke server baru atau dilacak ulang kerusakan sudah sejauh apa.

Oleh karena itu agar efektif suatu organisasi harus mempersiapkan rencana pemulihan bencana yang terdiri atas:

1. Filosofi organisasi, visi, misi, dan tujuan yang berhubungan dengan rencana pemilihan dan kelanjutan usaha

2. Penunjukan Komite Eksekutif Manajemen Bencana untuk mengambil tindakan dalam situasi tidak adanya Dewan Direksi

3. Arahan-arahan yang jelas dan lingkup pemulihan bencana berdasarkan penilaian risiko

4. Tugas-tugas, autoritas, dan tanggung jawab dari setiap karyawan untuk mengelola kondisi kritis

5. Rencana pemulihan organisasi untuk setiap cabang, departemen, fasilitas, dan fungsi dalam institusi

6. Peralatan untuk persiapan kondisi darurat bencana

7. Dokumentasi yang baik uji coba dan proses evaluasi dari rencana pemulihan bencana yang dilakukan pada beberapa interval tertentu 
8. Program pelatihan yang komprehensif untuk semua karyawan yang dilakukan dalam interval tertentu minimal setahun sekali. Pelatihan dapat berisi materi tentang identifikasi dan penggunaan peralatan, pemetaan area bencana, dasar-dasar pertolongan pertama dan teknik kelangsungan hidup, penjelasan mengenai tanggung jawab masingmasing dalam situasi bencana

9. Kopi tertulis dari rencana pemulihan bencana akhir yang disebarkan kepada setiap cabang dan pimpinan departemen

Sebagai lokasi penelitian, BPN sendiri belum memiliki manajemen resiko atas bencana. Hal ini nampaknya masih banyak terjadi di instansi pemerintahan. Instansi pemerintahan cenderung abai atas resiko-resiko tersebut, mayoritas dikarenakan merasa tidak ada nya rasa kepemilikan atas aset. Berbeda dengan swasta yang merasa bahwa aset merupakan property sehingga keamanannya perlu dijaga. Melalui penelitian ini peneliti berharap dapat menjadi gambaran apa saja yang perlu dilakukan oleh instansi pemerintahan dalam manajemen resiko perlindungan arsip vital mereka.

\section{KESIMPULAN}

Pada dasarnya, arsip vital yang dikelola oleh BPN DIY adalah cermin dari proses administrasi yang terjadi dalam pelaksanaan fungsi-fungsi BPN DIY tersebut. Jika berdasar pada proses administrasi, maka arsip vital yang tercipta tidak hanya berupa arsip sertifikat tanah, tetapi juga termasuk buku register tanah, peta atau denah ruang, data hasil survei pertanahan. BPN DIY, sebagai pembuat kebijakan dan penetapan keputusan hak pertanahan, tidak akan dapat menjalankan fungsinya apabila arsip buku register tanah maupun peta atau denah ruang tersebut rusak, bahkan hilang.

Secara umum BPN melakukan pengelolaan arsip dnegan sistem kombinasi. Pengelolaan arsip vital sendiri belum memiliki standar manajemen bencana. Hal seperti ini terjadi di banyak instansi permerintahan karena rasa abai dari pegawai atas aset milik organisasi. Konsep DRCP mengenalkan tentang 3 tahapan penanganan bencana yaitu tahapan pre bencana, pada saat bencana dan pasca bencana. Ketiga tahapan tersebut sebaiknya dituangkan dalam dokumen SOP penanganan bencana suatu organisasi. Selain itu tahapan tersebut dapat dimulai dari tahapan pengidentifikasian aset vital, identifikasi bencana yang mungkin terjadi, identifikasi manajemen pelindungannya serta tupoksi masing-masing pegawai terhadap mekanisme penanganan bencana tersebut.

\section{DAFTAR PUSTAKA}

Ricks, Betty . 1992. Information and Image Management : A Records System Approach. South Western Publishing Lo : Ohio

Penn, Ira A., Gail Pennix and Coulson. 1994. Records Management Handbook. Gower : USA

Ismayati, Nita. 2015. "Preservasi Arsip Vital Perguruan Tinggi: Studi Kasus di Universitas x." Jurnal Pustakawan Indonesia 13.2

Krihanta. 2013. Pengelolaan Arsip Vital, Jakarta: UT Press

Sulistyo Basuki. 2003. Manajemen Pengelolaan Arsip Dinamis. Jakarta : PT. Gramedia Pustaka Utama 
Shaluf, Ibrahim Mohamed. 2007. "An Overview On Disasters", Disaster Prevention And Management Vol. 16 iss: 5 pp. $687-703$

Wawancara dengan pihak BPN 22 September 2017. 